\title{
日本工業大学 機械工学科 プラスチック成形加工研究室
}

\section{1. 大学の概要}

日本工業大学は, 田園と住宅地が広がる埼玉県の東南, 東武日光線と伊勢崎線が分岐する東武動物公園駅の近くに ある. 本学の開学は, 昭和 42 年ということであるから, かれこれ 40 年近くの歴史を持つ私立の単科大学である. 本学については, 佐々木哲夫本学元教授が, 本誌において, 過去に紹介されているので1), ここでは, 若干視点を変え て本学の特徵を紹介する。

本学は, 機械工学科をはじめとする 5 学科に, 約 5000 名の学生が在籍している. ほとんどの学生が, 工業高校出 身者である.これらの学生に, 技能の習得が中心であった 高校教育から, さらに進めて, ものづくりに必要な創造力 を高めるための，より高度な実践教育を行うことを教育理 念としている. そのため, 昭和 52 年には大学院も設置さ れ，現在に至っている。また，最近のトピックスとしては， 本年 4 月に技術経営 (MOT) の専門職大学院が東京神田 に開校した. 本学には, 機械工学科に関係のあるものとし て, ダイヤモンドをはじめとする新材料の合成技術，およ びナノ・マイクロテクノロジー等の最先端技術開発を行っ ている先端材料技術研究センター, そして, 産学連携によ るファインブランキングセンター等の付属施設, さらに, 年商数億円のベンチャービジネス企業もあり, 学生の研究 教育の大きな力となっている．筆者が最も気に入っている のが, 明治初期から現代までの工作機械を集めた工業技術 博物館である. 館内には, かつての町工場が復元された展 示もある. 工作機械にとどまらず，ダイカストマシンや， 最近では，歴史的価值のある射出成形機が日精樹脂工業か ら寄贈され展示されている.さらに，19世紀末の英国製 蒸気機関車も展示されており, 図 1 に示すように, 学内に 敷かれた線路を，なんと，実際に汽笛を上げながら走る.

\section{2. 研究室の概要}

筆者は，本学に着任して今年で 3 年目に入る。題目のよ うに「プラスチック成形加工研究室」の看板を揭げている. 現在の当研究室のメンバー構成は, 博士後期学生 1 名, 博 士前期学生 1 名, 4 年生 15 名, 3 年生 8 名, 合計 25 名の

\footnotetext{
* Murata, Yasuhiko

日本工業大学機械工学科

埼玉県南埼玉郡宮代町学園台 4-1（†345-8501）

2005.4.21 受理
}

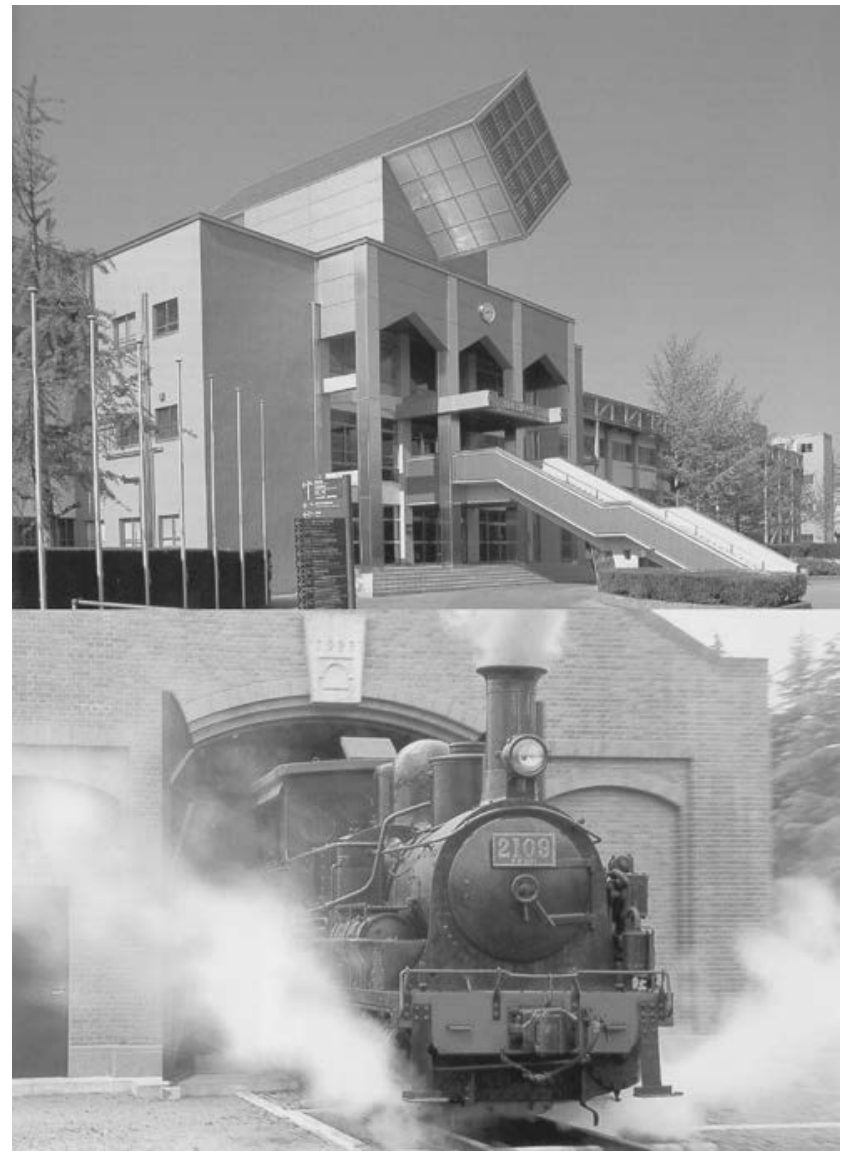

図 1 最上階にソーラーシステムが設置された本館および 学内を走る蒸気機関車

大所帯である (図 2 は昨年度在籍者)。本学では, 3 年生 になった時点で研究室に配属され，来るべき卒業研究の準 備をするといった珍しいシステムを取っている．たった一 人で， 25 名の学生の面倒を見るのは，非常に骨が折れる. 当研究室では, 射出成形金型を主な研究対象としている. 筆者の前職場である東京大学生産技術研究所横井研究室 に在籍中に行っていた，金型内成形プロセスおよび成形不 良現象の計測ツールの開発，および計測ツールを用いた現 象解析を引き続き実施し，優れた金型を設計するために必 要不可欠な情報の蓄積を行っている。 また, 近年, 流行の ナノ・マイクロテクノロジーにも注目し，マイクロ成形金 型の設計・製作，およびマイクロ部品成形技術の検討も開 始しており，大きなものから小さなものまで，“金型”に 


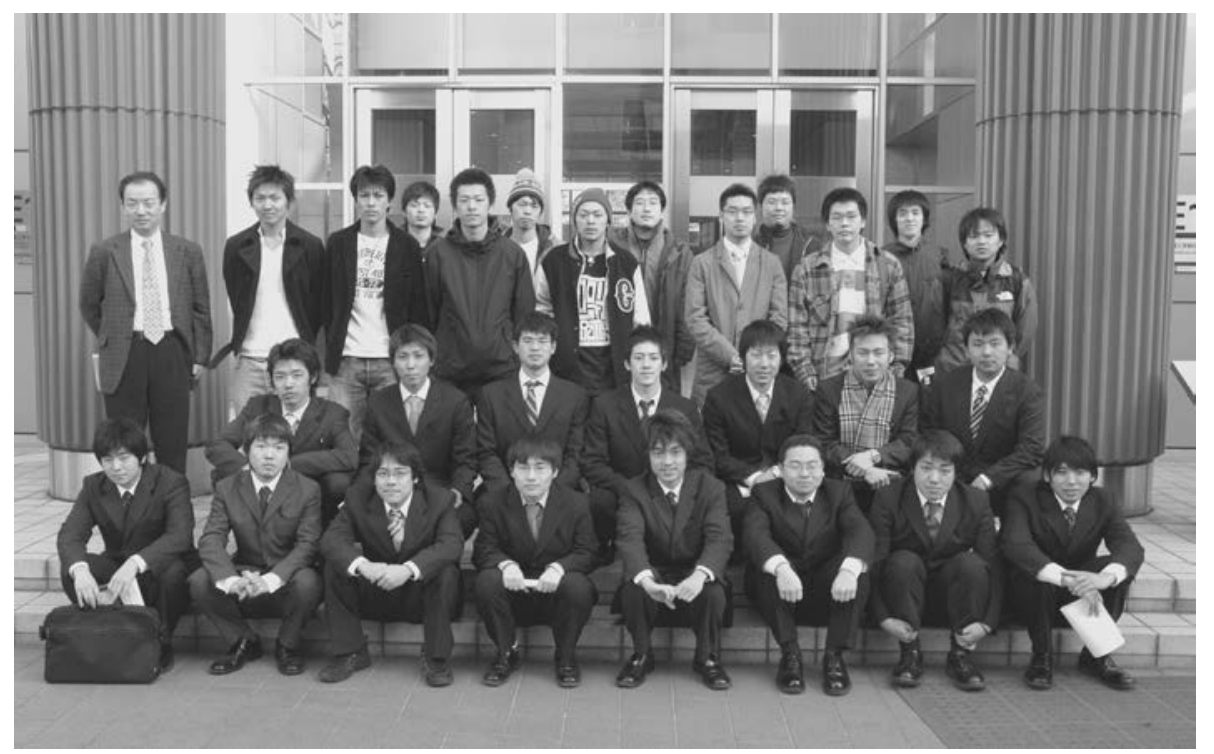

図 2 プラスチック成形加工研究室のメンバー

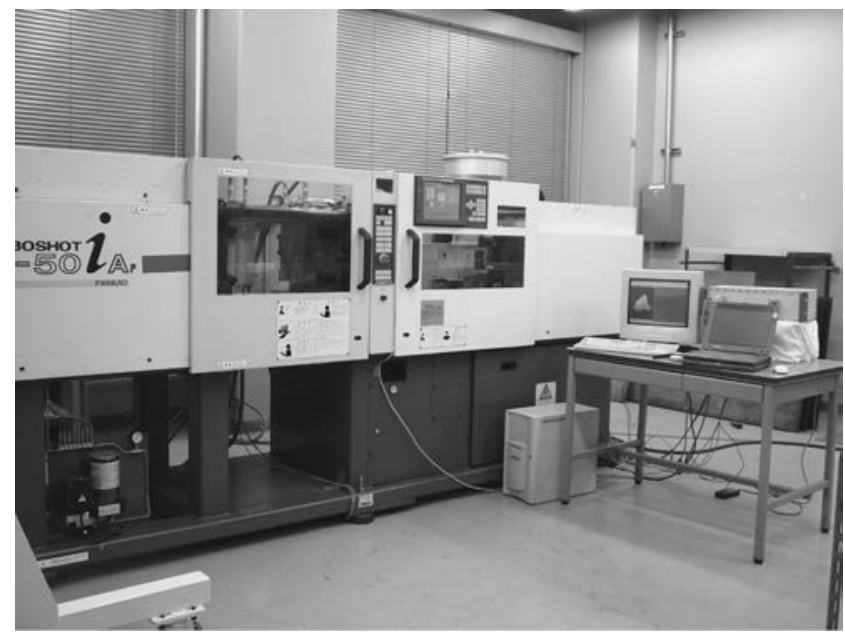

図 3 実験装置

纏わる研究を行っている．以下に，当研究室で行っている 研究の概要について紹介する.

\section{3 . 研 究内容}

\section{1 キャビティ面圧力分布計測}

新しい成形法の登場に伴い，成形プロセスはさらに複雑 化し，また新たな不良現象が発生する。当研究室では，型 内成形プロセス抢よび不良現象解明の一環として，圧力伝 達ピンアレイと多点圧力計測用の触覚センサとから構成さ れるキャビティ面圧力分布計測手法を用いて，金型キャビ ティ面に作用する樹脂圧力分布の計測を行っている（図 3 は，射出成形機 ファナック製 ROBOSHOT $\alpha-50 \mathrm{iAp}$ と計 測装置)。本計測手法は, 前職場における共同研究プロジェ クトの中で開発したものである ${ }^{2)}$. 当研究室では，本手法 を用いて，各種キャビティ・ゲート形状あるいは各種樹脂 に打けるキャビティ面圧力分布 ${ }^{3)}$ ，また，図 4 に示すよう な, ウェルドライン生成過程に押ける面圧力分布 ${ }^{4}$ の解析 を行っている.さらに, 新成形プロセスの現象解析にも取 り組んでおり，埼玉県産業技術総合センターと共同で，超 臨界発泡射出成形時における面圧力分布計測 ${ }^{5}$ も行ってい

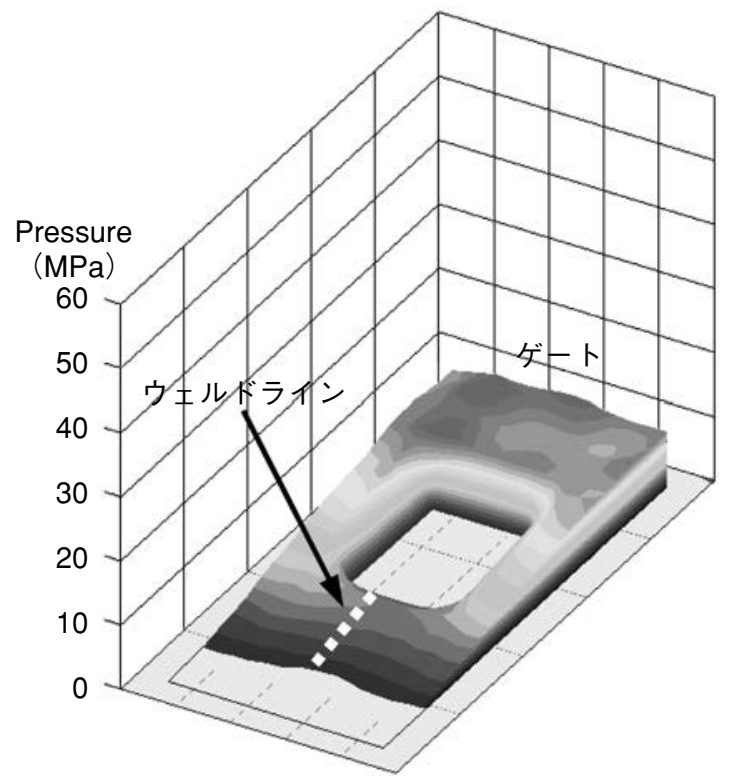

図 4 ウェルドライン生成時のキャビティ面圧力分布 (樹脂：沉用ポリスチレン) ${ }^{4)}$

る. 図 5 は，矩形平板の中央に縦リブが設けられたキャビ ティに扔ける計測事例である。冷却過程において，リブ部 上で長時間にわたって樹脂圧力が保持され，その結果，ひ けの低減がもたらされることを実証的に示した。

\section{2 マイクロ部品成形技術の検討}

文科省の私立大学ハイテクリサーチセンター整備事業の 一環として，集束イオンビーム（FIB）加工を用いた微細 形状キャビティの製作，そして，上記キャビティが挿入さ れたマイクロ成形金型と重錘落下式超高速射出成形機を用 いたマイクロ成形部品の製作を行っている6. 図 6 は，手 のひらサイズのマイクロ成形金型，および微細形状キャビ ティの外観を示している．本金型と重錘落下式超高速成形 機により，図 7 に示すような，肉眼では確認でない，外形 $50 \mu \mathrm{m}$ の星形部品を成形した．図中に見られるようなバ リの発生抑止，および離型性の向上が今後の課題となって いる. 


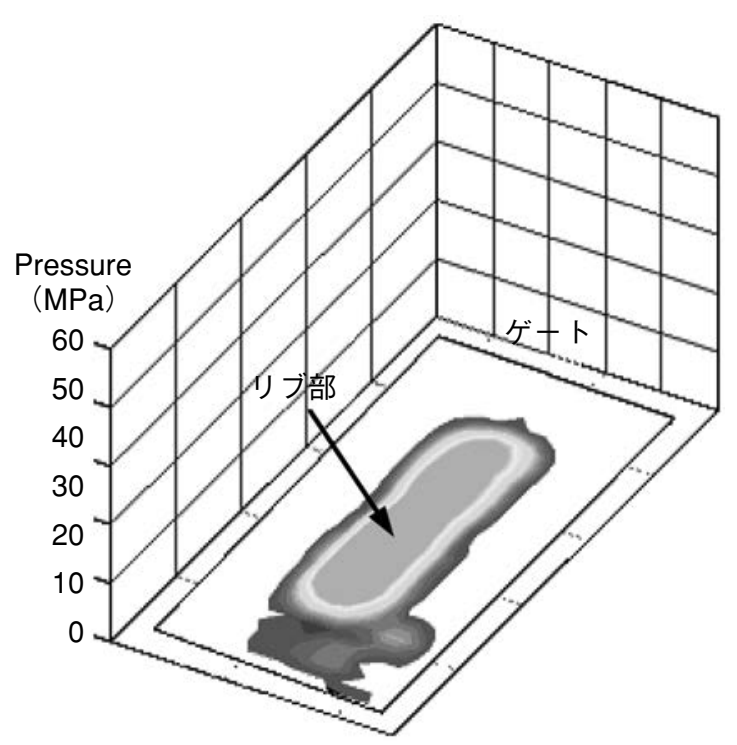

図 5 超臨界発泡射出成形時のキャビティ面圧力分布 (樹脂：耐衝撃性ポリスチレン) ${ }^{5)}$

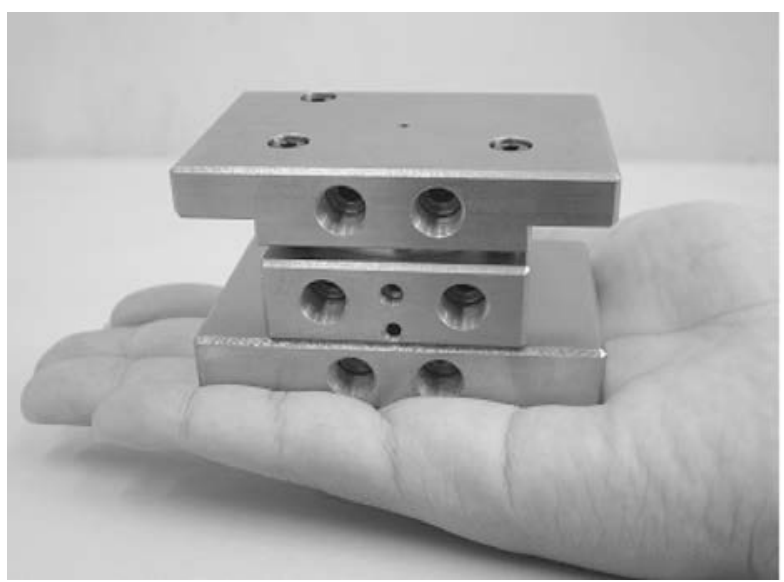

図 6 マイクロ成形金型と FIB 加工装置によって彫られた微細形状キャビティ ${ }^{6)}$
この他にも，可視化を用いない，簡易で安価な樹脂充填 パターン計測手法確立を目指した，強制ゲートシャット機 構を用いたショートショット法 ${ }^{7)}$, 射出成形 CAE を用い た成形不良の発生因子の検討などを行っている。

筆者は，学生時代に大阪市立工業研究所にお世話になり， よい勉強をさせていただいた経験がある。学生が，“井の 中の蛙”にならないように，高度な研究設備・水準に触れ てもらう意味で, 理化学研究所に学生を派遣し, そこで精 密研削加工, あるいは高速ミーリング加工等に関する研究 の指導をいただいている.

\section{4.おわりに}

学生の教育が今では, 課せられた重要な仕事の一つと なっている，今後は，ものづくりに注力した，具体的には， “金型づくり”，“製品づくり”を中心とした研究教育を推 し進め，プラスチック業界の発展のために努力する所存で
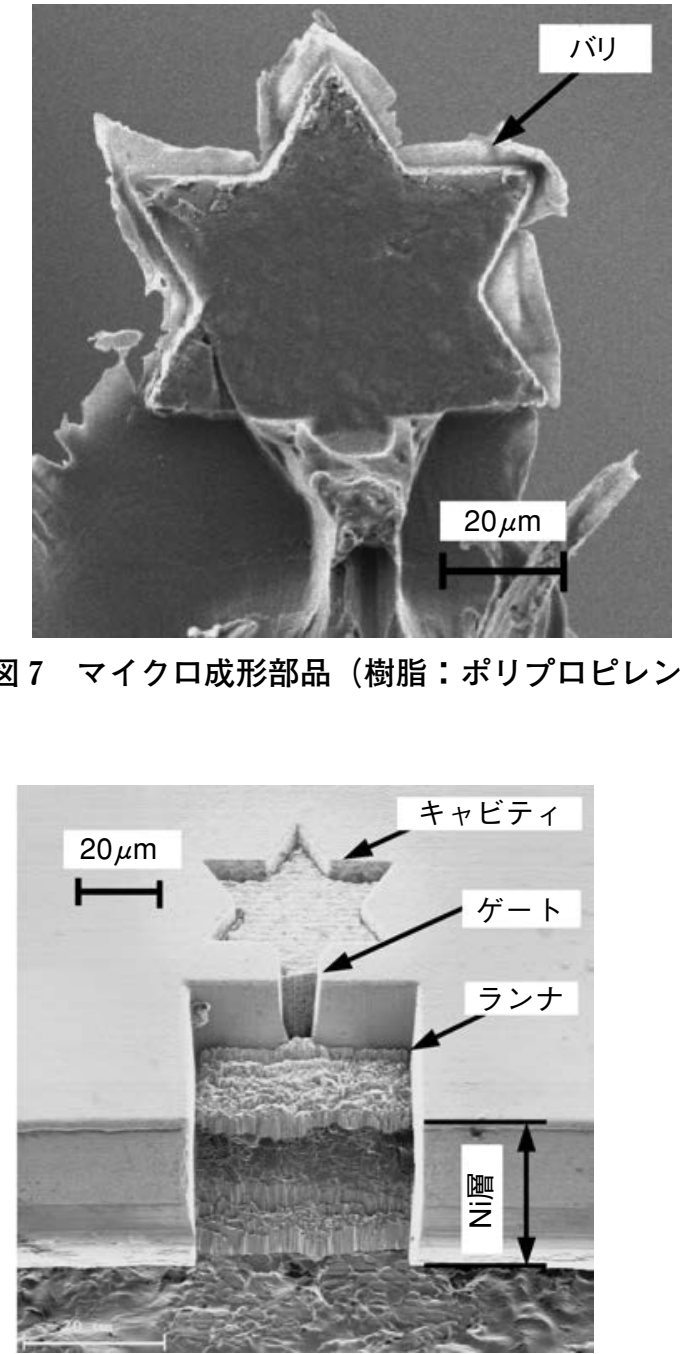

図 7 マイクロ成形部品（樹脂：ポリプロピレン $)^{6)}$
ある. 当研究室に関心のある方は, 是非, 足をお運びいた だければ幸いである。

\section{参 考 文 献}

1）佐々木哲夫：成形加工，12(7)，437（2000）

2 ）村田泰彦, 横井秀俊, 河崎浩志：成形加工, 8(4), 249 (1996)

3 ) 村田泰彦, 忽滑谷晃博, 横井秀俊 : 成形加工, 235 (2004)

4 ) 村田泰彦, 真板 健, 竹内 匠, 忽滑谷晃博, 横井秀 俊：成形加工シンポジア'04，61（2004）

5 ) 村田泰彦, 山田岳大, 石井博之, 忽滑谷晃博, 横井秀 俊：成形加工 ’04，321（2004）

6 ）村田泰彦, 堤 崇光, 新井好房, 野口裕之：2005 年 度精密工学会春講論，CD-ROM； File No.K 79 (2005)

7 ) 村田泰彦, 市野和洋, 宮脇真之：2005 年度精密工学 会春講論, CD-ROM ; File No.K 63 （2005） 